\title{
Planning Reactivation Train for Kedungjati - Tuntang Using Google Earth, Global Mapper, and AutoCAD Civil 3D
}

\author{
Dhiya Ayu Nuswanti \\ Railway Building and Track \\ Technology \\ Indonesia Railway Polytechnic \\ Madiun, Indonesia \\ dhiyaayunuswantari@yahoo.co.id
}

\author{
Moch. Zusuf Mahendra \\ Railway Building and Track \\ Technology \\ Indonesia Railway Polytechnic \\ Madiun, Indonesia \\ zusuf.tbjp1627@taruna.api.ac.id
}

\author{
Adya Aghastya \\ Railway Building and Track \\ Technology \\ Indonesia Railway Polytechnic \\ Madiun, Indonesia \\ adya@ppi.ac.id
}

\begin{abstract}
Kedungjati - completion road is a railway line that has not been used, and it used to connect between Semarang and Secang, Magelang Regency. In accordance, with the 2011 National Railway Master Plan (RIPNAS), the Directorate General of Railways of the Ministry of Transportation stated that the need for by development of development areas and railway services in Indonesia. The Kedungjati - Tuntang Railway is a route from Semarang to the National Tourism Strategic Area (KSPN) of Borobudur Temple so that the route needs to be reactivated. The software that will be used is Google Earth, Global Mapper, and the Civil 3D AutoCAD. The software is easy to apply, accurate and structured to plan reactivation of the railway. The method that will be used is to run all three software with sequential work systems from Google Earth, Global Mapper, and 3D Civil AutoCAD in a structured manner. The data obtained from the planning results are the plan speed of $112.5 \mathrm{~km} / \mathrm{h}$, minimum radius of $440 \mathrm{~m}, 99 \mathrm{~m}$ transition curve, $30.6 \mathrm{~km}$ track length, 25 per mile maximum slope, maximum $110 \mathrm{~mm}$ rail elevation, and rail elevation minimum of $60.46 \mathrm{~mm}$.
\end{abstract}

Keywords: Google Earth, Global Mapper, 3D Civil AutoCAD, horizontal alignment, vertical alignment, Kedungjati - Tuntang Railway

\section{INTRODUCTION}

Kedungjati railroad railway line is a railway line that is dead or inoperative, once this line connected between Semarang and Secang in Magelang Regency. The line, built by the Nederlands Indische Spoorweg Maatschappij (NISM) in 1871 and completed in 1905, passed three stations, namely: Tempuran Station, Gogodalem Station, and Bringin Station and Ngombak and Tlogo Shelters which used to be used as loading and unloading timber.

In 1970, Tuntang Station was also used as cattle transportation to be transported to Jakarta, the lack of service and the development of the train at that time made the people choose highways such as national and toll roads because it was considered safer, more efficient and faster. In 1976 the Kedungjati - Tuntang railway was officially closed. Because it was unable to compete with existing modes of transportation on the highway, for 40 years the line was not activated, and the components of the upper structure of the railroad were still visible.
In accordance with the 2011 National Railroad Master Plan (RIPNAS), the Directorate General of Railways of the Ministry of Transportation explained that the target of the railway network and service development to be achieved by 2030 is one of which is $12.100 \mathrm{~km}$ of the national railroad (spread on Java, Bali, Sumatra, Sulawesi, Kalimantan, and Papua) [1]. It is planned to be able to serve passenger travel of 929.5 million people/year, including passenger trips in 15 urban areas and goods, with a total of 995.5 million tons/year.

Reactivation needs to be done on the KedungjatiTuntang route intended to reactivate the SemarangMagelang railway line which will be the link between Ambarawa, Jogjakarta, and Magelang where there are tourist attractions of Borobudur Temple. Borobudur Temple will be a priority for access to the National Tourism Strategic Area (KSPN) combined with the National Railway Master Plan (RIPNAS) in 2011.

\section{RESEARCH METHOD}

The basis of the author in completing this study is as follows:

- PM No. 60 of 2012 concerning the technical requirements of the Railroad Line [2]

- Service Regulation No.10 of 1986 as a reference in planning railroad structural components

Informing and completing this study, literature is needed regarding railways, railroad planning, railroad reactivation, and Ministry of Transportation regulations.

TABLE I. TyPES AND FUNCTIONS OF SUPPORTING DATA

\begin{tabular}{|l|l|}
\hline \multicolumn{1}{|c|}{ Data Type } & \multicolumn{1}{c|}{ Data function } \\
\hline Long Section & $\begin{array}{l}\text { As a basis for planning railways that } \\
\text { will be activated }\end{array}$ \\
\hline Output data Google & $\begin{array}{l}\text { Knowing earth and global height of } \\
\text { surface Mapper surface elevation } \\
\text { and basic contour of geometric } \\
\text { planning of railroad }\end{array}$ \\
\hline Field survey results & Documentation \\
\hline
\end{tabular}


Based on TABLE I, route planning does not need to be done because the cycle uses existing or inactive railroad tracks, so the geometry calculations used include [3]:

1) Horizontal alignment: curved circles, transitional arches, train width, and elevation.

2) Vertical alignment: positive and negative curvatures, and calculation of the height of each STA.

After obtaining vertical alignment data and structural details, it will be used to create cross-s ectional images of each STA, which is then used to calculate the excavation volume and heap.

\section{RESULTS AND DISCUSSION}

The stages of analysis included making contours using the Google Earth and Global Mapper applications, determining design criteria, horizontal and vertical curvature improvements from the obtained data traces, making longitudinal and transverse pieces and pile excavation volumes and mass haul diagrams [4].

\section{A. Land Contour}

This location pin in Google Earth (based on Fig. 1) serves to give a starting point and endpoint for the Kedungjati - Tuntang reactivation path planning at Kedungjati Station and ends at Tuning Station.

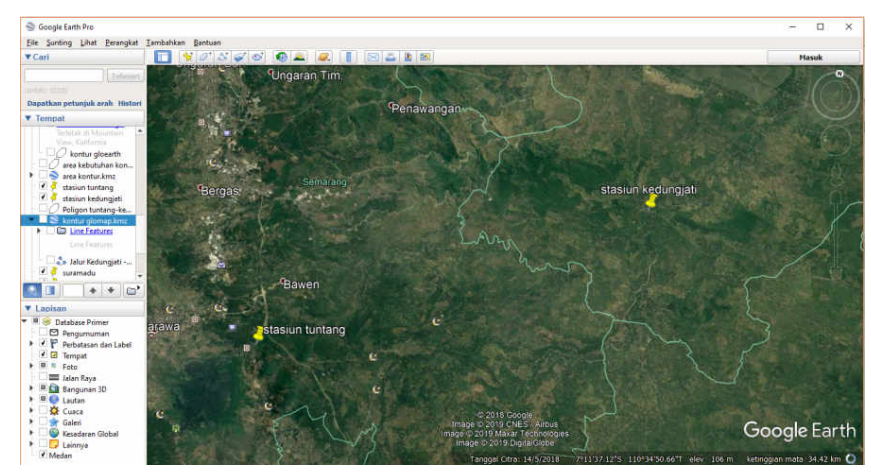

Fig. 1. Pin Location.

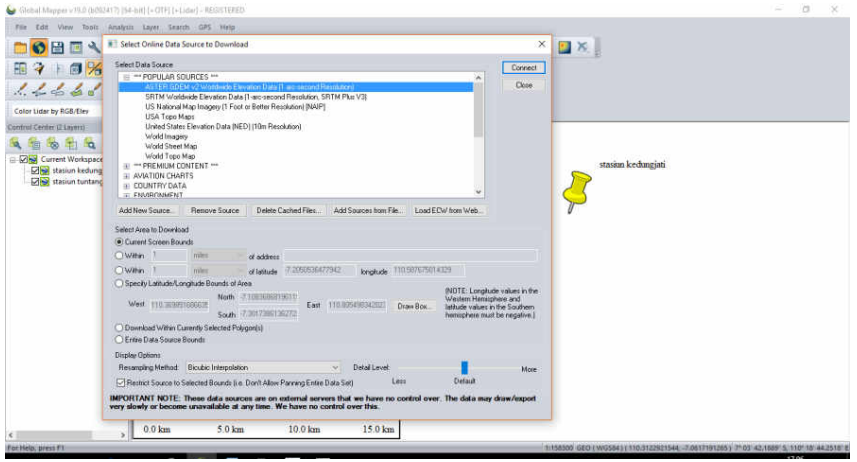

Fig. 2. Import to Global Mapper.

In this global Mapper application in Fig. 2, locations that have been marked on Google Earth will be imported and linked to the actual condition map so that the land contour will automatically be found. This land contour will be saved to DEM format so that it can be opened in the Civil 3D application.
Then open the Civil 3D application (Fig. 3), select the setting drawing, then set the zone category according to the location to be studied, UTM WGS84 Datum, then select the coordinate system UTM - WGS84, zone 49 south, meter, cent, meridian $111 \mathrm{~d}$. After setting the zone and coordinates then return to the prospector right-click surface create a surface from DEM then click where the automatic contour (Fig. 4) will appear. The sit long data plot that has been obtained on the contour.

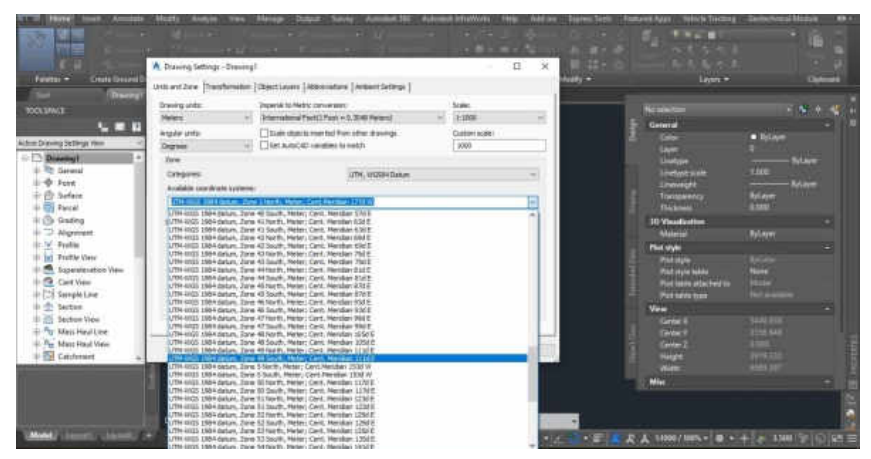

Fig. 3. Import Contour Civil 3D.

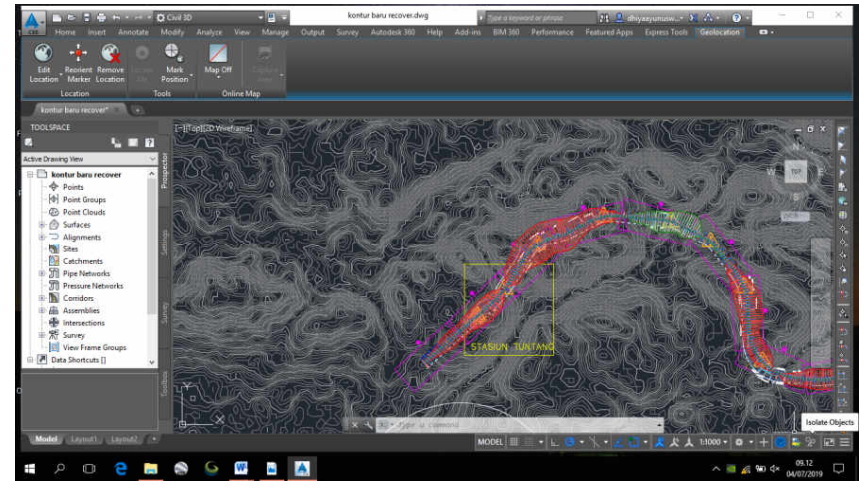

Fig. 4. Contour.

\section{B. Design Criteria}

In alignment properties in Fig. 5, there are several tabs. The information tab can be selected by rail because the design that will be made is the railway. In this type, there is another menu that can be chosen to design in addition to the railroad, namely the highway.

The station control in the Fig. 6 tab contains information about the $\mathrm{X}$ and $\mathrm{Y}$ coordinate reference points and stations. Station $0+000.00$ is the initial station which is in coordinates $\mathrm{X}=439222.2973$ and $\mathrm{Y}=9197502.0802$. Then there is information on the length of the rail design which is $15946.624 \mathrm{~m}$ with a start $0+000.00 \mathrm{~m}$ and end $15+946.62 \mathrm{~m}$. 


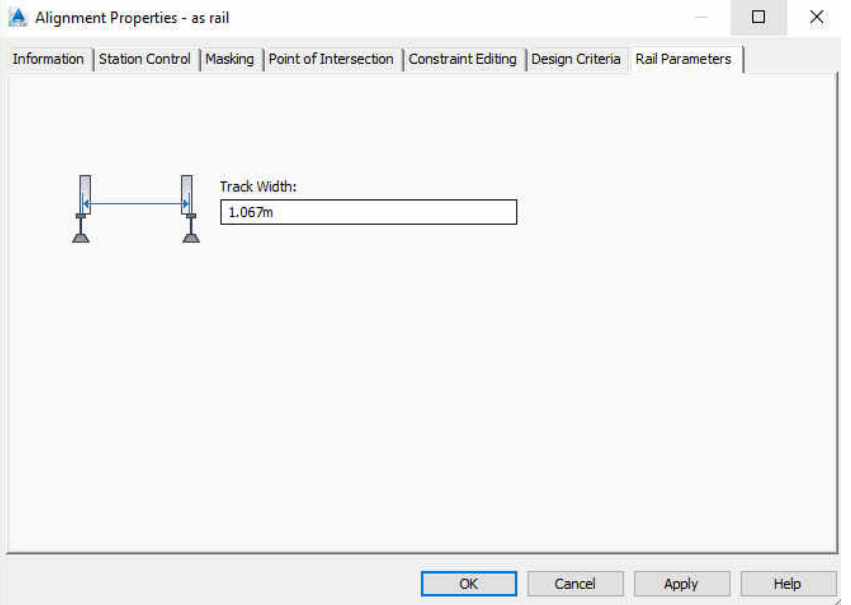

Fig. 5. Alignment Properties.

Fig. 8. Rail Parameter.

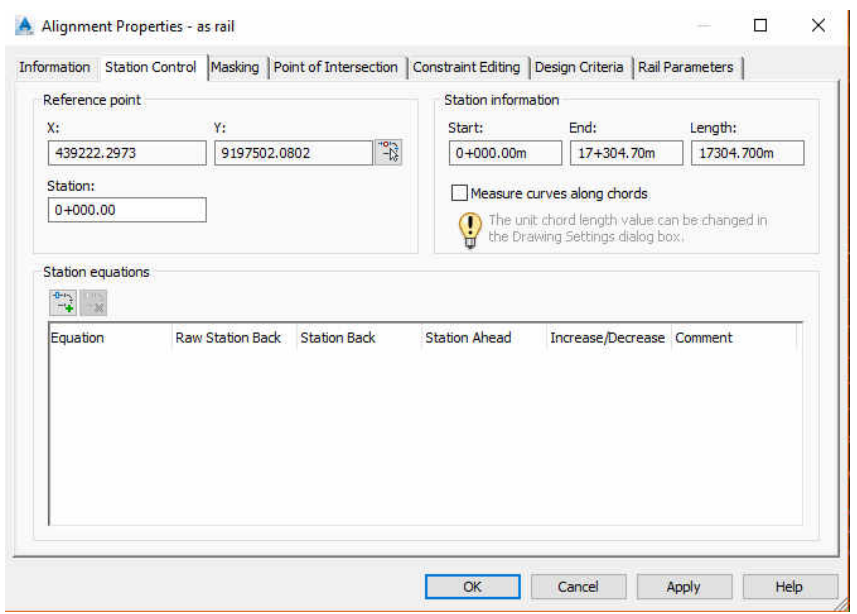

Fig. 6. Station Control.

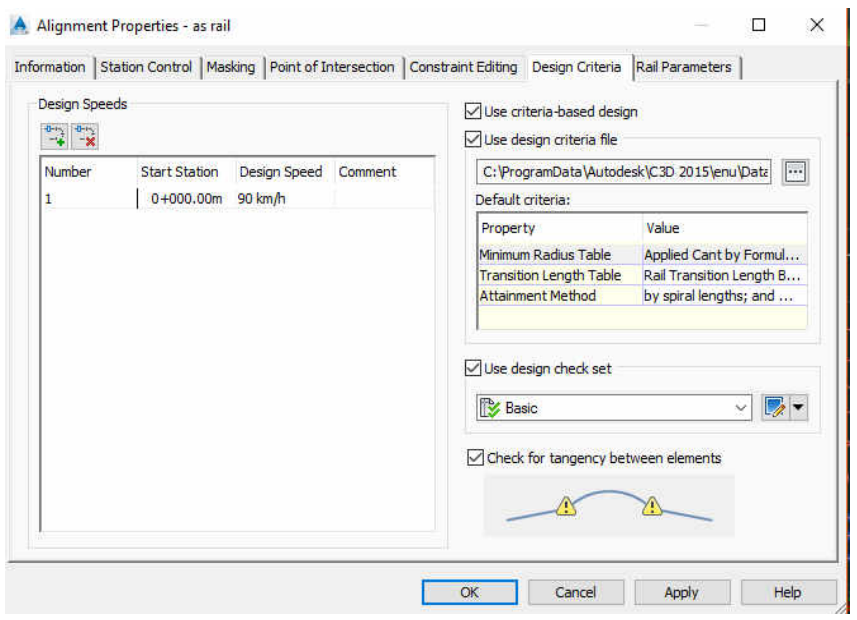

Fig. 7. Design Criteria.

According to the road class classification [2], the maximum speed used for road class 4 is $90 \mathrm{~km} / \mathrm{h}$, then the design criteria include a spe ed of $90 \mathrm{~km} / \mathrm{hr}$ (Fig. 7). Then to find out whether the curve to be made is a problem or not the check for tangency between elements box is checked.

In this section, the research er can determine the width of the railway to be used in the plan, which is $1067 \mathrm{~m}$. In this subassembly properties, it is complete rail parameters ranging like Fig. and Fig. 9 from the slope of the rail, the width of bearing, bearing width, bearing height, ballast width, ballast depth, ballast slope, sub-ballast width, subballast depth, and sub slope reply. Can be filled according to road class 4 planning [2] for 1: 2 ballast slope and ballast sub slope 1: 1.5. Sepur width is $1067 \mathrm{~m}$, bearing width $2 \mathrm{~m}$, ballast width $1.9 \mathrm{~m}$, width sub-ballast $3 \mathrm{~m}$.

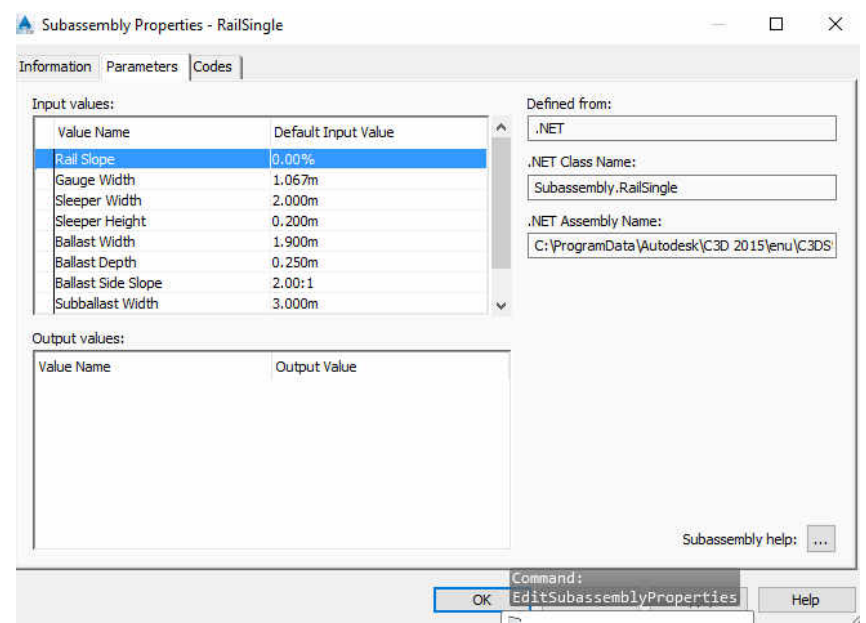

Fig. 9. Subassembly Properties.

\section{Alignment Horizontal}

Based on the data received by the researcher, the horizontal alignment of the Kedungjati-Tuntang tract has 25 curves that must be repaired if using road class 4 specifications [2]. For the arch types used are spiral-circlespiral and spiral-spiral (full circle). 


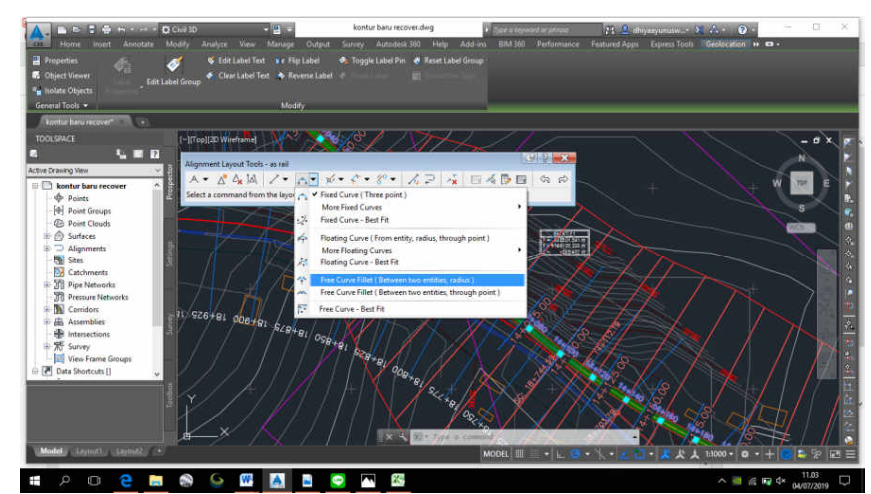

Fig. 10. FC Curve Repair.

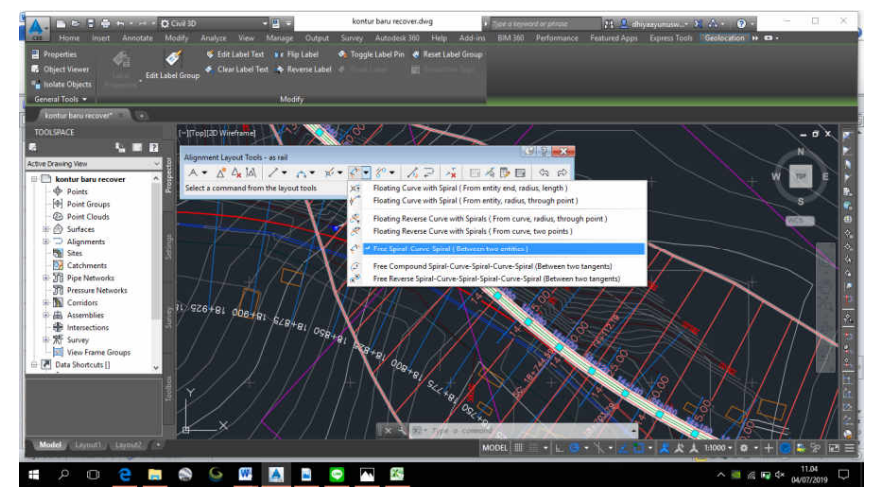

Fig. 11. SCS Curve Repair.

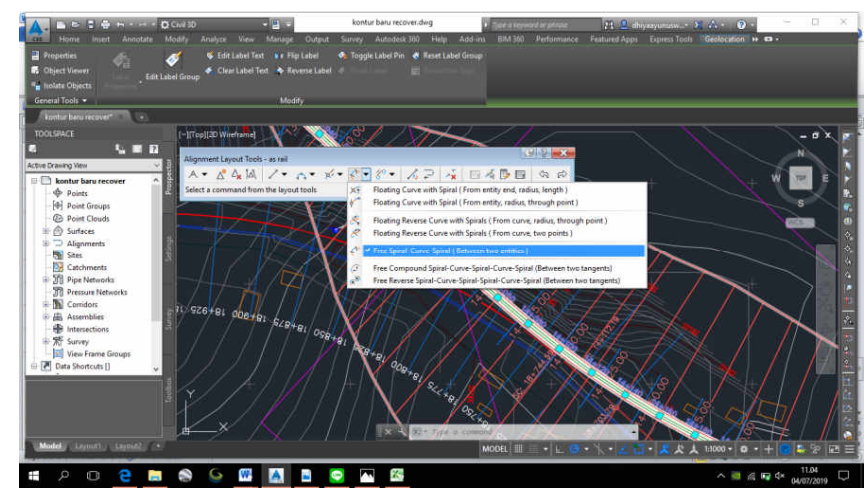

Fig. 12. Alignment Horizontal.

Before redesigning using the civil 3D application liked Fig. 10, Fig. 11 and Fig. 12, a manual calculation was perform ed to correct the curvature that had $\mathrm{R}$ less than 440 $\mathrm{m}$ with the transition and $1330 \mathrm{~m}$ without the intermediate curve. After the numerical calculation is obtained, it can be inputted using the Civil 3D application, and then automatically a curved repair will appear.

\section{Alignment Vertical}

Vertical alignment on the second phase - the improvement has also been improved for class 4 class classification [2], the maximum allowed slope is $25 \%$. Vertical alignment planning (TABLE II) in the civil 3D application starts with the starting point STA $0+000.00$ with the initial elevation $491.658 \mathrm{~m}$ and STA $4+300$ elevations $475,000 \mathrm{~m}$ liked Fig. 13. Based on the TABLE III, the slope between these two points is $2.3 \%$ under the provisions of $25 \%$ and between STA $4+300$ to STA $9+800$ has a slope of $22.7 \%$.

TABLE II. VERTICAL ALIGNMENTCALCULATION

\begin{tabular}{|l|l|l|l|l|}
\hline No. & $\begin{array}{c}\text { PVI } \\
\text { Station }\end{array}$ & $\begin{array}{c}\text { PVI } \\
\text { Elevation }\end{array}$ & Grade In & Grade Out \\
\hline 1. & $0+000$ & 491,658 & & $2,3 \%$ o \\
\hline 2. & $4+300$ & 475,000 & $22,7 \% 0$ & \\
\hline
\end{tabular}

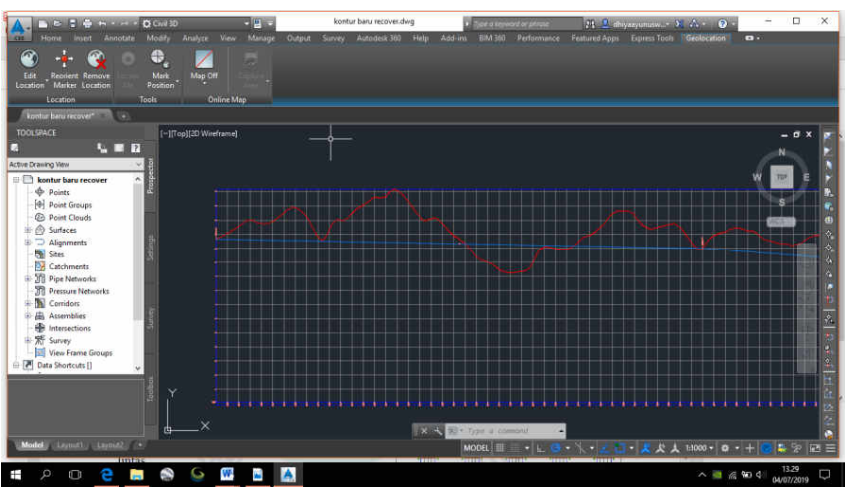

Fig. 13. Alignment Vertical STA 0+000 until STA 4+300.

\section{E. Crossing the Cross}

On the cross-section in Fig. 14 and Fig. 15 of the railroad can be seen the structure of the railroad is divided into two parts, namely the upper structure and the lower structure.

1) The upper structure (superstructure): rail, bearing, tethering, and wesel.

2) The bottom structure (substructure): reply, sub replied, basic land, and natural land.

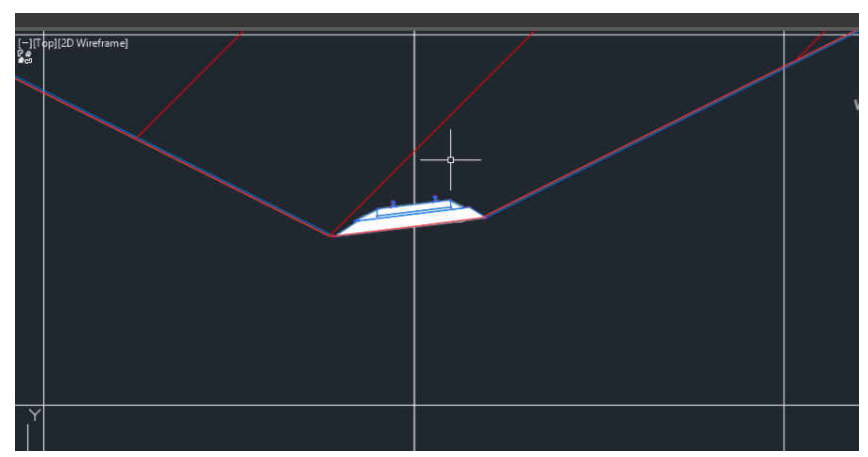

Fig. 14. STA Crossing Examples.

\section{F. Minerals and Stacks Volume}

Excavations and heaps are a very important part of the work in the construction of railroads [5]. Then a detailed calculation is needed so that the planned volume of excavation and stockpiles is by the conditions in the field and does not create a budget of high costs. With the civil 3D application, researchers try to display the area count of one cross-section and the volume between two adjacent cross-sections. The distance between the STA that is made is $25 \mathrm{~m}$ so that it is expected to obtain the volume of land that approaches the original conditions in the field. 


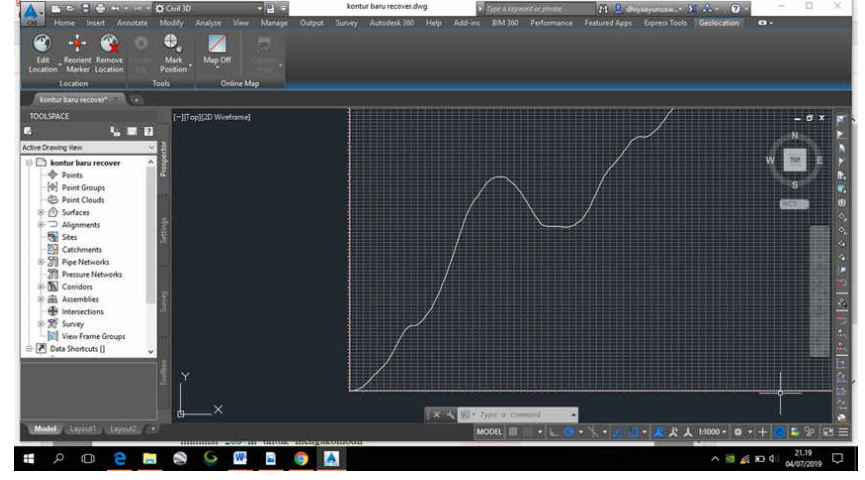

Fig. 16. Mass Haul Diagram.

Fig. 16 shows that the excavation work is on a rising curve, and the curve area decreases for embankment work. be taken to get the most economical use of the plan.

From all the cross-sections that have been calculated, the cumulative excavation is $26126671.62 \mathrm{~m}^{3}$, and the cumulative heap is $842906.91 \mathrm{~m}^{3}$ so that the figure can indicate that the site requires a lot of excavated land.

\section{G. Mass Haul Diagram}

Mass Haul Diagrams (MHDs) are used to compare the economics of various methods of distribution of earthworks on-road or railroad construction schemes [6]. With the combined use of mass haul diagrams plotted directly under the longitudinal part of the survey centerline, it can be found the distance at which the excavation and heap will be balanced. The amount of material moved and directed of movement. Areas where land may have to be stockpiled or
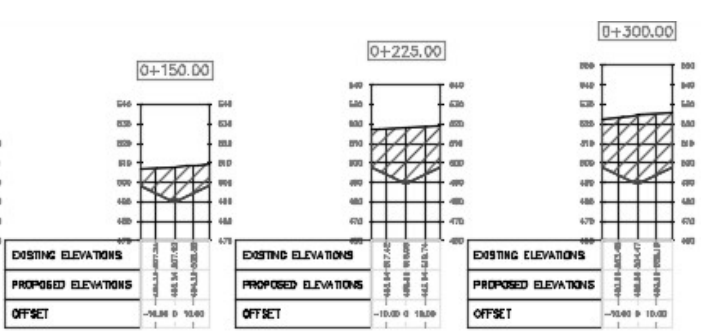

$0+250.00$
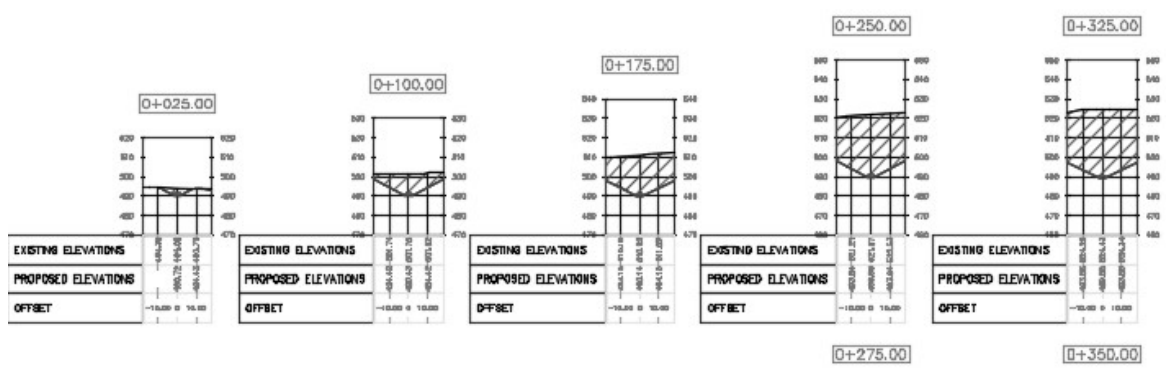

$\square+350.00$
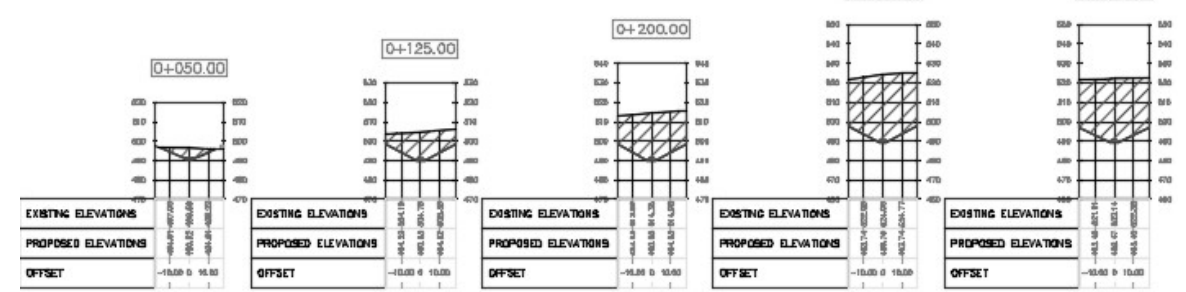

Fig. 15. TA cross-section to STA.

TABLE III. CALCULATION OF EXCAVATIONAND STOCKSEVERY $25 \mathrm{M}$

\begin{tabular}{|c|l|l|l|l|l|l|}
\hline \multicolumn{7}{|c|}{ Total Volume Table } \\
\hline Station & Fill Area & Cut Area & Fill Volume & Cut Volume & $\begin{array}{c}\text { Cumulative } \\
\text { Fill Volume }\end{array}$ & $\begin{array}{c}\text { Cumulative } \\
\text { Cut Volume }\end{array}$ \\
\hline $0+000.00$ & 0.00 & 0.00 & 0.00 & 0.00 & 0.00 & 0.00 \\
\hline $0+025.00$ & 1.83 & 37.16 & 22.84 & 464.55 & 22.84 & 464.55 \\
\hline $0+050.00$ & 2.22 & 96.43 & 50.58 & 1669.93 & 73.43 & 2134.48 \\
\hline $0+075.00$ & 0.00 & 185.09 & 27.74 & 3518.99 & 101.17 & 5653.47 \\
\hline $0+100.00$ & 0.00 & 281.63 & 0.00 & 5833.92 & 101.17 & 11487.39 \\
\hline $0+125.00$ & 0.00 & 392.94 & 0.00 & 8432.08 & 101.17 & 19919.47 \\
\hline $0+150.00$ & 0.00 & 508.41 & 0.00 & 11266.89 & 101.17 & 31186.35 \\
\hline $0+175.00$ & 0.00 & 618.84 & 0.00 & 14090.59 & 101.17 & 45276.94 \\
\hline $0+200.00$ & 0.00 & 745.26 & 0.00 & 17051.19 & 101.17 & 62328.13 \\
\hline $0+225.00$ & 0.00 & 884.99 & 0.00 & 20378.07 & 101.17 & 82706.20 \\
\hline $0+250.00$ & 0.00 & 1023.66 & 0.00 & 23858.12 & 101.17 & 106564.32 \\
\hline $0+275.00$ & 0.00 & 1098.21 & 0.00 & 26523.40 & 101.17 & 133087.71 \\
\hline
\end{tabular}




\begin{tabular}{|c|l|l|l|l|l|l|}
\hline \multicolumn{7}{|c|}{ Total Volume Table } \\
\hline Station & Fill Area & Cut Area & Fill Volume & Cut Volume & $\begin{array}{c}\text { Cumulative } \\
\text { Fill Volume }\end{array}$ & $\begin{array}{c}\text { Cumulative } \\
\text { Cut Volume }\end{array}$ \\
\hline $0+300.00$ & 0.00 & 1120.76 & 0.00 & 27737.16 & 101.17 & 160824.88 \\
\hline $0+325.00$ & 0.00 & 1119.76 & 0.00 & 28008.58 & 101.17 & 188831.43 \\
\hline $0+350.00$ & 0.00 & 1048.46 & 0.00 & 27106.49 & 101.17 & 215937.92 \\
\hline $0+375.00$ & 0.00 & 979.43 & 0.00 & 25352.32 & 101.17 & 241290.24 \\
\hline $0+400.00$ & 0.00 & 940.37 & 0.00 & 23997.41 & 101.17 & 265287.65 \\
\hline $0+425.00$ & 0.00 & 944.96 & 0.00 & 23566.59 & 101.17 & 288854.24 \\
\hline $0+450.00$ & 0.00 & 955.50 & 0.00 & 23755.76 & 101.17 & 312610.00 \\
\hline $0+475.00$ & 0.00 & 1001.83 & 0.00 & 24466.65 & 101.17 & 337076.65 \\
\hline
\end{tabular}

\section{Conclusions}

The research conducted can be summarized as follows:

1. Horizontal alignment consists of 25 curves that must be corrected for the curvature used, namely spiral-circlespiral and spiral-spiral (full circle). A manual calculation is performed to correct the curvature that has $\mathrm{R}$ less than $440 \mathrm{~m}$ with the transition and $1330 \mathrm{~m}$ without the intermediate curve.

2. Vertical alignment is improved with a maximum allowed slope of $25 \%$. Vertical alignment planning in the civil 3D application starts with the starting point STA $0+000.00$ with the initial elevation $491,658 \mathrm{~m}$ and STA $4+300$ elevations $475,000 \mathrm{~m}$. The slope between these two points is $0.39 \%$ under the provisions of $25 \%$ and between STA $4+300$ to STA $9+800$ has a slope of $22,7 \%$. With the civil 3D application, researchers try to display the area count of one cross-section and the volume between two adjacent cross-sections. The distance between the STA that is made is $25 \mathrm{~m}$ so that it is expected to obtain the volume of land that approaches the original conditions in the field.
3. From all the cross-sections that have been calculated, the cumulative excavation is $26,126,671.62 \mathrm{~m}^{3}$, and the cumulative heap is $842,906.91 \mathrm{~m}^{3}$ so that the figure can indicate that the site requires a lot of excavated land.

\section{REFERENCES}

[1] Republic of Indonesia. 2018. Decree of Minister Transportation Republic of Indonesia number KP 2128 of 2018 concerning the Master Plan of the National Railway (in Indonesian). Jakarta: Ministry of Transportation, 2018.

[2] Republic of Indonesia. Regulation of Minister Transportation number 60 of 2012 concerning the Technical Requirements of Railroad Lines (in Indonesian). Jakarta: Ministry of Transportation, 2012.

[3] Mughni, M and Chasanah, F., Planning of the Reactivation Jogja Parangtritis Railroad Route (in Indonesian). Civil Engineering Journal and UII Planning. Yogyakarta, 2013.

[4] Aghastya Adya, Tamtomo Wahyu A. API Madiun Outer Ring Toll Planning Uses Autocad Civil 3D (in Indonesian). Indonesian Railways Journal Vol. 1 No. 2 ISSN 2550-1127, 2017.

[5] Rosyidi, Sri Atmaja P. Dictates on Railroad Structure Enginee ring (in Indone sian). http://atmaja.staff.umy.ac.id/files/2012/03/BAB-XPERENC-GEOMETRIK-JALAN-REL.pdf. 2018. Downloaded on Augst, 3th 2019.

[6] Slideshare. Topic 3 Mass Haul Diagram (in Indonesian). https://www .slideshare .net/kmasz/topic-3-mass-haul-diagram, 2011. Downloaded on July, 4th 2019. 